Wilfrid Laurier University

Scholars Commons @ Laurier

4-1994

\title{
Examining the Contributions of Glacial Till Water to Storm Runoff using Two- and Three-Component Hydrograph Separations
}

\author{
M.J. Hinton \\ University of Waterloo \\ Sherry L. Schiff \\ University of Waterloo \\ Michael C. English \\ Wilfrid Laurier University, menglish@wlu.ca
}

Follow this and additional works at: https://scholars.wlu.ca/geog_faculty

\section{Recommended Citation}

Hinton, M.J.; Schiff, Sherry L.; and English, Michael C., "Examining the Contributions of Glacial Till Water to Storm Runoff using Two- and Three-Component Hydrograph Separations" (1994). Geography and Environmental Studies Faculty Publications. 11.

https://scholars.wlu.ca/geog_faculty/11

This Article is brought to you for free and open access by the Geography and Environmental Studies at Scholars Commons @ Laurier. It has been accepted for inclusion in Geography and Environmental Studies Faculty Publications by an authorized administrator of Scholars Commons @ Laurier. For more information, please contact scholarscommons@wlu.ca. 


\title{
Examining the contributions of glacial till water to storm runoff using two- and three-component hydrograph separations
}

\author{
M. J. Hinton and S. L. Schiff \\ Waterloo Centre for Groundwater Research, University of Waterloo, Waterloo, Ontario, Canada
}

M. C. English

Department of Geography, Wilfrid Laurier University, Waterloo, Ontario, Canada

\begin{abstract}
Two- and three-component hydrograph separations based on ${ }^{18} \mathrm{O}$ and dissolved silica are used to investigate the contributions of glacial till water to the storm runoff of a headwater stream on the Canadian Shield. Two-component isotopic hydrograph separations based on ${ }^{18} \mathrm{O}$ indicate that the volume and flux of event water could be accounted for by direct precipitation onto saturated areas. Three-component hydrograph separations distinguish between event water, preevent soil water, and preevent till water. These results show that groundwater flow through coarse-textured glacial tills can make a significant contribution to stream discharge during runoff events (29 and $62 \%$ in this study) despite the lower hydraulic conductivities of the tills compared to the overlying soils. The three-component hydrograph separations also demonstrate that the relative contributions of preevent soil water and preevent till water changed during one runoff event such that the average water chemistry of the preevent component varied during the event. Two-component hydrograph separations using dissolved silica indicate that seasonal changes in the till water contributions also occur and are related to groundwater levels. Measurements of vertical hydraulic gradients during runoff events indicate that the increase in flow from the tills to the soils is minimal and cannot account for the large and rapid increase in till water flow into the stream. Till water that has discharged to the soils prior to the event is probably being flushed from the soils into the stream during events.
\end{abstract}

\section{Introduction}

Hydrograph separations based on chemical or isotopic mass balances of stream discharge are commonly used to determine the relative contributions of event (new) water and preevent (old) water as sources of streamflow during runoff events [Bottomley et al., 1984, 1986; Hooper and Shoemaker, 1986; Moore, 1989; Wels et al., 1991a]. Changes in the relative contributions of these waters are then used to infer changes in hydrological processes and flow paths during runoff generation [Sklash and Farvolden, 1979; Sklash et al., 1986; McDonnell et al., 1991; Wels et al., 1991b]. Hydrograph separations have been a common tool in studies of the hydrochemistry of forested catchments because knowledge of the sources and flow paths of water during runoff events aid in the development of conceptual and mathematical models of stream discharge and stream water chemistry [Christophersen et al., 1982; Gherini et al., 1985].

The results of hydrograph separations in humid forested catchments underlain by crystalline bedrock generally indicate that old water (commonly assumed to be groundwater or a mixture of groundwater and soil water) comprises approximately $30 \%$ to nearly $100 \%$ of stream discharge during storms in low-order catchments [Fritz et al., 1976; Sklash, 1986; Maulé and Stein, 1990; Rodhe, 1981, 1984,

Copyright 1994 by the American Geophysical Union.

Paper number 93WR03246.

0043-1397/94/93WR-03246\$05.00
1987; Bishop, 1991]. Despite the numerous similarities in the physical characteristics among many of these catchments, there appears to have been little attempt to relate hydrograph separation results to physical and hydrological factors. Large variations in the hydrograph separation results between several events within a single catchment suggest that the wide range of hydrological conditions present in the catchments during these runoff events may be responsible for much of these variations. Since hydrograph separations measure the relative fluxes of new and old water to the stream, the results should be influenced by both precipitation intensity and groundwater flux to the stream. Summarizing the results of 37 runoff events in 10 catchments, Rodhe [1987] showed that the average proportion of groundwater discharged during the events was negatively correlated to both the rate of water input to the catchments and to the maximum specific discharge of the streams. Few studies have used the results of hydrograph separations to investigate the physical and hydrological factors that result in rapid old water flow to the stream during runoff events.

Several investigators have demonstrated the importance that groundwater levels have on runoff generation. Groundwater levels influence the discharge of both the new and old water components of storm runoff. Rising groundwater levels result in the expansion of groundwater discharge areas that are impermeable to incident precipitation and cause both overland flow and return flow to the stream [Dunne et al., 1975]. Furthermore, numerical modeling by Sklash and Farvolden [1979], and laboratory and field experiments by 
Abdul and Gillham [1984, 1989] and Blowes and Gillham [1988] have shown that rising groundwater levels adjacent to the stream can also result in increased hydraulic gradients and groundwater discharge into the streambed.

Much of the Northern hemisphere is covered by glacial till deposits. The presence of compacted layers and clay-sized particles can significantly reduce the hydraulic conductivities of these tills. In shallow flow systems where tills are underlain by low-permeability bedrock, groundwater flow through these tills is frequently assumed to be negligible relative to flow through the overlying soils [Espeby, 1989; Likens et al., 1977]. However, the texture, mineralogy, and petrology of glacial tills are very variable both regionally and stratigraphically and frequently are related to the bedrock geology of the source rock [Karrow, 1979]. On the Canadian Shield, the texture of glacial tills generally has a small proportion of clay-sized sediment [Scott, 1979] and may consequently have hydraulic conductivities that are sufficiently large to transmit a significant proportion of the groundwater flow through these catchments. Such flow may also significantly influence stream chemistry, since the residence times of groundwater are likely to be greater in the tills than in the soils resulting in higher chemical concentrations in discharging till waters. The extreme spatial variability of the hydraulic properties of the tills greatly complicates the hydrometric monitoring of flow through these sediments and the interpretation of these results so that hydrograph separations are a useful tool in examining the overall significance of groundwater flow through the tills.

Hydrograph separations based on chemical and isotopic data are used in this paper with the purpose of examining the relative importance of groundwater discharge through soils and tills to a Canadian Shield stream during stormflow conditions. Three specific hypotheses are addressed. First, groundwater that has flowed through glacial till (till water) is an important component of stream discharge during runoff events. Second, the proportion of till water discharging to the stream varies both seasonally and during storm events and is related to groundwater levels. Last, the use of hydrometric data can improve our interpretations of flow paths inferred from hydrograph separations.

\section{Study Site}

The study site is Harp 4-21, a small 3.7-ha headwater catchment located within the Harp Lake catchment in the Muskoka-Haliburton region of central Ontario (Figure 1). Stream discharge from Harp 4-21 is perennial and accounts for approximately $35 \%$ (1988-90) of the mean annual precipitation of $1033 \mathrm{~mm}$ (1976-1989) (Ontario Ministry of the Environment (MOE), unpublished data, 1991). Approximately two thirds of the annual streamflow occurs between March 1st and June 30th when groundwater levels are highest due to spring melt and rainstorms. A general description of the hydrogeology of the catchment is provided by Hinton et al. [1993].

The catchment is underlain by metamorphic Canadian Shield bedrock composed predominantly of amphibolite and schist [Jeffries and Snyder, 1983]. The overburden in Harp 4-21 forms an unconfined aquifer consisting of glacial tills overlain by Podzolic soils. The tills are relatively coarse consisting predominantly of sandy loams with $0-24 \%$ claysized particles and substantial quantities of pebble to boulder size material (S. N. Dankevy, unpublished manuscript, 1989). The overburden is up to $15 \mathrm{~m}$ thick in the northwestern upslope portion of the catchment and gradually thins to between 2 and $6 \mathrm{~m}$ beneath the stream [Hinton et al., 1993]. A horizontally discontinuous layer of compact till (densipan) is often observed within or at the base of the soil profile at depths ranging up to $1.2 \mathrm{~m}$. This layer is most prominent in the upper half of the catchment. Compact tills are also found at greater depths $(>2.5 \mathrm{~m})$ in the upper catchment but there are insufficient data to determine the horizontal extent of these layers. The physical and chemical characteristics of the soils in the Harp 4 catchment are summarized by Lozano et al. [1987].

\section{Methods}

The monitoring network consists of 89 piezometers and five stream sampling locations (Figure 1). A more detailed description of instruments and sampling procedures is provided in the work by Hinton et al. [1993]. The glacial tills in Harp 4-21 have a large range of horizontal hydraulic conductivities from $2.6 \times 10^{-5} \mathrm{~m} / \mathrm{s}$ to $1.8 \times 10^{-9} \mathrm{~m} / \mathrm{s}(n=56)$ with a geometric mean of $2.3 \times 10^{-7} \mathrm{~m} / \mathrm{s}(95 \%$ confidence interval of the mean from $1.0 \times 10^{-7}$ to $5.1 \times 10^{-7} \mathrm{~m} / \mathrm{s}$ ). Four drive point piezometers have conductivities of less than $1 \times 10^{-9}$ $\mathrm{m} / \mathrm{s}$. This range is typical for glacial tills and silty sands [Freeze and Cherry, 1979] and emphasizes the heterogeneous nature of the Harp 4-21 tills. The horizontal hydraulic conductivities of the soils vary over a much smaller range from $3.0 \times 10^{-5}$ to $3.7 \times 10^{-7} \mathrm{~m} / \mathrm{s}(n=13)$ with a geometric mean of $2.7 \times 10^{-6}(95 \%$ confidence interval of the mean from $1.4 \times 10^{-6}$ to $\left.5.2 \times 10^{-6} \mathrm{~m} / \mathrm{s}\right)$. The absence of horizons of low hydraulic conductivity results in higher effective hydraulic conductivities in the soils [Hinton et al., 1993].

Fifteen runoff events were monitored between March 1989 and May 1990. Stream discharge was recorded continuously at S1 using a float-operated water level recorder and manually at S3, S4, and S5 (Figure 1). Discharge at S2 is assumed to equal the difference between discharge at $\mathrm{S} 1$ and $\mathrm{S} 3$, since the surface area contributing directly to $S 1$ is small. Surface saturated area was estimated using piezometric data and visual observations of surface ponding. This method probably overestimates surface saturated areas, since it also includes unsaturated hummocks between surface saturated hollows. Stream water samples were collected at all five stream sites ( $\mathrm{S} 1$ to $\mathrm{S} 5$ ) during both base flow and storm flow conditions with the exception of the June 22, 1989, storm which was sampled only at $\mathrm{S} 1$. Groundwater samples were collected from piezometers screened from 0.15 to $6.7 \mathrm{~m}$ depths in the soils and in the tills, and soil water samples were collected using tension and zero-tension lysimeters (Figure 1). Throughfall samples were collected in 20-L pails lined with plastic sample collection bags. Molybdate reactive dissolved silica $\left(\mathrm{SiO}_{2}\right.$, expressed in milligrams $\mathrm{Si}$ per liter) was analyzed by colorimetry, and major cations $\left(\mathrm{Ca}^{2+}\right.$, $\mathrm{Mg}^{2+}, \mathrm{Na}^{+}, \mathrm{K}^{+}$) were analyzed by atomic absorption spectroscopy by the $M O E$ [1983]. Rain and snow chemistry samples are collected weekly by the MOE at the precipitation site (Figure 1). Selected samples were also analyzed for ${ }^{18} \mathrm{O} /{ }^{16} \mathrm{O}$ ratios (reported as per mil difference relative to SMOW with a precision of $\pm 0.2 \%(1 \sigma)$ ) at the University of Waterloo for isotopic hydrograph separations. 


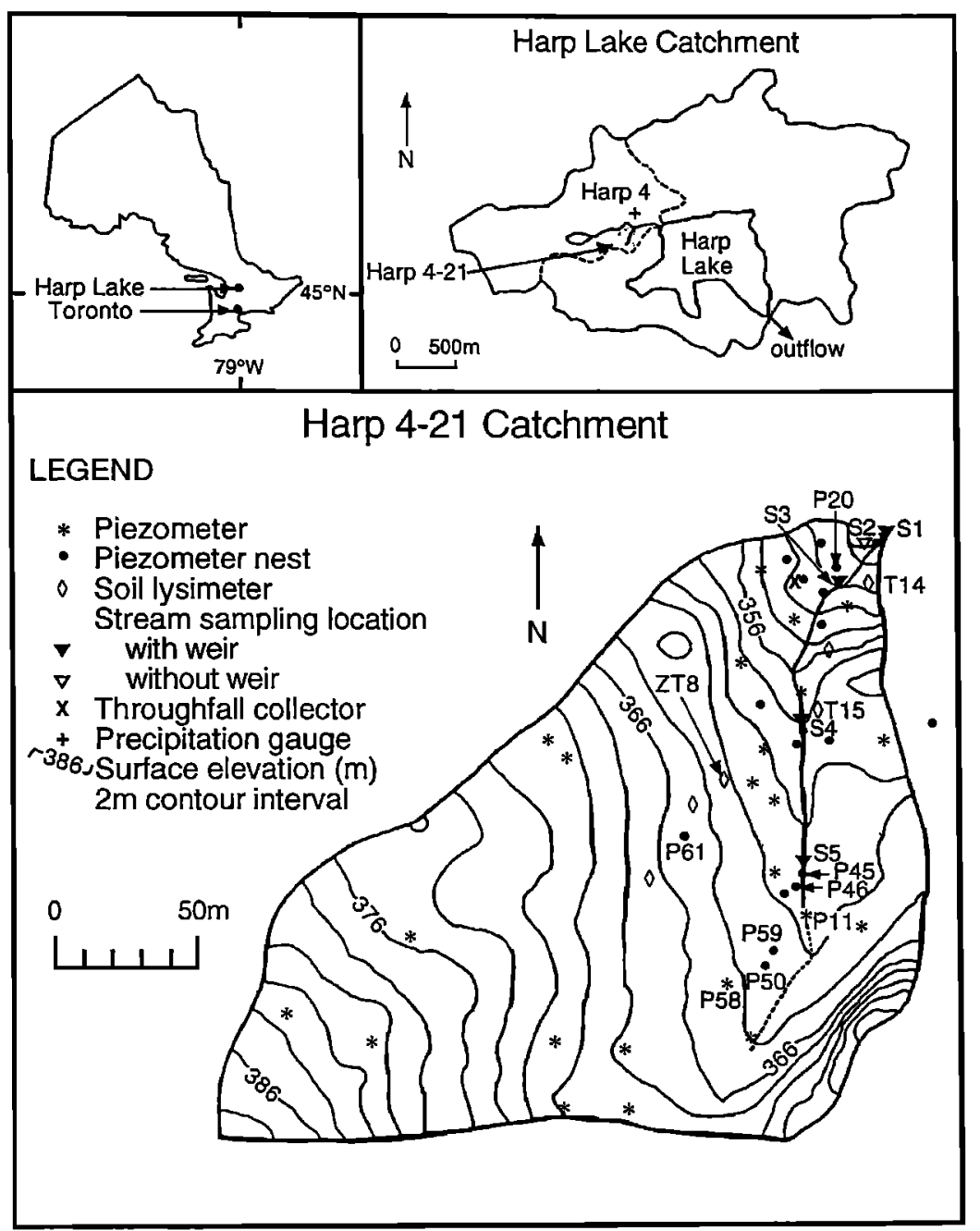

Figure 1. Location map and instrumentation of the Harp 4-21 catchment. Piezometers P20, P46, P59, and P11 were sampled for groundwater ${ }^{18} \mathrm{O}$, and lysimeters $\mathrm{ZT} 8, \mathrm{~T} 14$, and T15 were sampled for soil water ${ }^{18} \mathrm{O}$.

\section{Hydrograph Separation}

Hydrograph separation consists of quantifying the various sources contributing to stream discharge. For two sources contributing to streamflow, the proportions of old and new water discharge in the stream water are determined from the equations

$$
\begin{aligned}
& \frac{Q_{o}}{Q_{s}}=\frac{\left(C_{s}-C_{n}\right)}{\left(C_{o}-C_{n}\right)} \\
& \frac{Q_{n}}{Q_{s}}=\frac{\left(C_{s}-C_{o}\right)}{\left(C_{n}-C_{o}\right)}
\end{aligned}
$$

where $C$ is the concentration of the chemical species, and the subscripts $o, n$, and $s$ refer to old, new, and stream water, respectively.

A chemical mass balance equation can be formulated for a three-component system:

$$
C_{o r} Q_{o t}+C_{o s} Q_{o s}+C_{n} Q_{n}=C_{s} Q_{s}
$$

where the subscripts ot and os refer to old till water and old water, respectively. This equation can be solved if either (1) the discharge of one of the components is known [DeWalle et al., 1988] or (2) two tracers are used simultaneously. Where two tracers such as isotopes (i) and dissolved silica (Si) are used, a set of linear equations can be solved for $Q_{n} / Q_{s}, Q_{o s} / Q_{s}$, and $Q_{o r} / Q_{t}$ :

$$
\begin{aligned}
\frac{Q_{n}}{Q_{s}}= & X_{n}=\left[\left(C_{s}^{\mathrm{si}}-C_{o s}^{\mathrm{Si}}\right)\left(C_{o t}^{\mathrm{i}}-C_{o s}^{\mathrm{i}}\right)\right. \\
& \left.-\left(C_{s}^{\mathrm{i}}-C_{o s}^{\mathrm{i}}\right)\left(C_{o t}^{\mathrm{Si}}-C_{o s}^{\mathrm{Si}}\right)\right]\left[\left(C_{n}^{\mathrm{Si}}-C_{o s}^{\mathrm{Si}}\right)\right. \\
& \left.\left(C_{o t}^{\mathrm{i}}-C_{o s}^{\mathrm{i}}\right)-\left(C_{n}^{\mathrm{i}}-C_{o s}^{\mathrm{i}}\right)\left(C_{o t}^{\mathrm{Si}}-C_{o s}^{\mathrm{Si}}\right)\right]^{-1} \\
& \frac{Q_{o s}}{Q_{s}}=X_{o s}=\left(\frac{C_{s}^{t}-C_{o t}^{t}}{C_{o s}^{t}-C_{o t}^{t}}\right)-X_{n}\left(\frac{C_{n}^{t}-C_{o t}^{t}}{C_{o s}^{t}-C_{o t}^{t}}\right) \\
& \frac{Q_{o t}}{Q_{s}}=X_{o t}=\left(\frac{C_{s}^{t}-C_{o s}^{t}}{C_{o t}^{t}-C_{o s}^{t}}\right)-X_{n}\left(\frac{C_{n}^{t}-C_{o s}^{t}}{C_{o t}^{t}-C_{o s}^{t}}\right)
\end{aligned}
$$




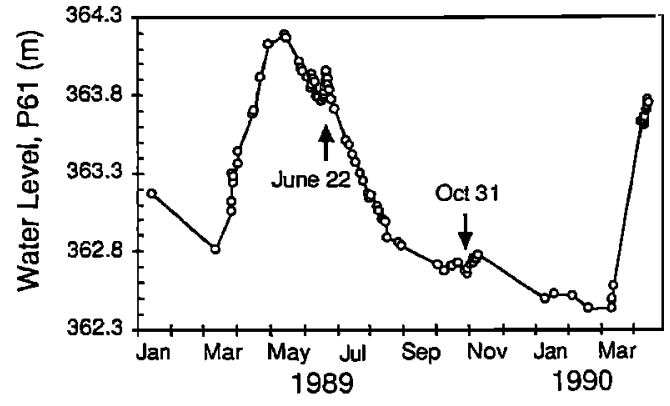

Figure 2. Seasonal variations in water levels in piezometer $\mathrm{P} 61$. The arrows indicate the June 22 and October 31 events.

Equations (5) and (6) can be applied using either of the tracers $(t=\mathrm{i}$ or $\mathrm{Si})$ provided that $C_{o t}^{t} \neq C_{o s}^{t}$ for the tracer used. Five assumptions are necessary to apply the threecomponent hydrograph separation: (1) the concentrations of each component must be distinct from the other two components for one or both of the tracers, (2) the concentrations of the three components cannot be collinear for the two tracers, (3) the average concentration of each component must remain constant for the duration of the event, (4) there are only three components (based on the concentrations of the two tracers) contributing to stream discharge, and (5) the tracers must mix conservatively. The interpretation of the three components in (3)-(6) obviously depends on the tracers used and the spatial and temporal patterns of their concentrations in the catchment under investigation. Wels et al. [1991a] used a three-component hydrograph separation (new overland flow, new subsurface flow, and old subsurface flow) for the special case where $C_{\text {new }}^{\mathrm{i}}$ oF $=C_{\text {new SSF }}^{\mathrm{i}}$ and

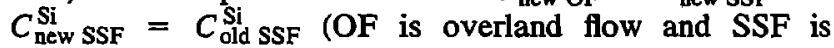
subsurface flow) which simplifies (4) and (6) to (2) (using $\mathrm{SiO}_{2}$ ) and (1) (using deuterium), respectively.

\section{Results and Discussion}

\section{Two-Component Hydrograph Separations Based on ${ }^{18} \mathrm{O}$}

Two-component hydrograph separations using ${ }^{18} \mathrm{O}$ ((1) and (2)) were used to determine the relative fluxes of new and old water for two storms with contrasting antecedent moisture conditions within the catchment. Groundwater levels prior to the June 22, 1989, rainstorm remained near their seasonal maximum in most of the catchment following spring melt and an 11-mm storm on June 20 (Figure 2). Four bursts of rainfall produced $36 \mathrm{~mm}$ of rain on June 22 resulting in four distinct peaks in stream discharge (Figure 3). The isotopic ratios of bulk throughfall samples from the first burst of rainfall $(-5.80 \%)$ and from the three remaining bursts of rainfall $(-5.75 \%$ ) are significantly different from the isotopic ratios of base flow following the storm $(-12.27 \%)$ and the average isotopic ratio of groundwater from four piezometers $(-12.32 \pm 0.12 \%)$, so that the uncertainty in the resulting hydrograph separations is less than $4 \%$ of the total flow. Despite high initial surface saturation $(\approx 8 \%)$ and rainfall intensities up to $12 \mathrm{~mm} / \mathrm{h}$, the old water component is always the dominant portion of stream discharge decreasing to a minimum of $56 \%$ near peak discharge and comprising $83 \%$ of the total stream discharge.

In the fall of 1989, groundwater levels were relatively low following a dry summer. Prior to the October 31, 1989, rainstorm, groundwater levels remained low following 11 days of dry, warm weather (Figure 2) and $\approx 3 \%$ of the catchment area remained saturated to the surface. The total rainfall for the storm was $19 \mathrm{~mm}$ with a maximum hourly intensity of $5.5 \mathrm{~mm} / \mathrm{h}$ (Figure 4). The isotopic ratio of stream base flow $(-11.83 \%$ ) prior to the storm is similar to the mean groundwater isotopic ratios from six piezometers $(-11.71 \pm$ $0.53 \%$ o) and is significantly different from the bulk throughfall $(-6.43 \%)$. The variation in old water isotopic ratios is considerably smaller than the difference between the new and old water concentrations such that the range in groundwater $a^{18} \mathrm{O}(-11.34 \%$ to $-12.37 \%$ ) corresponds to only a $7 \%$ error in the proportion of the total old water discharge. Even though the isotopic ratio of throughfall became more depleted as the storm progressed $(-5.66 \%,-6.18 \%$, and $-7.34 \%$; the isotopic ratio for the third portion of the storm was calculated to be $-7.34 \%$ by volume weighted difference from the bulk sample), this depletion results in less than a $3 \%$ error in the hydrograph separation if a cumulative mean of the new water is used as suggested by McDonnell et al. [1990]. The resulting two-component isotopic hydrograph separation for the October 31 storm shows that old water

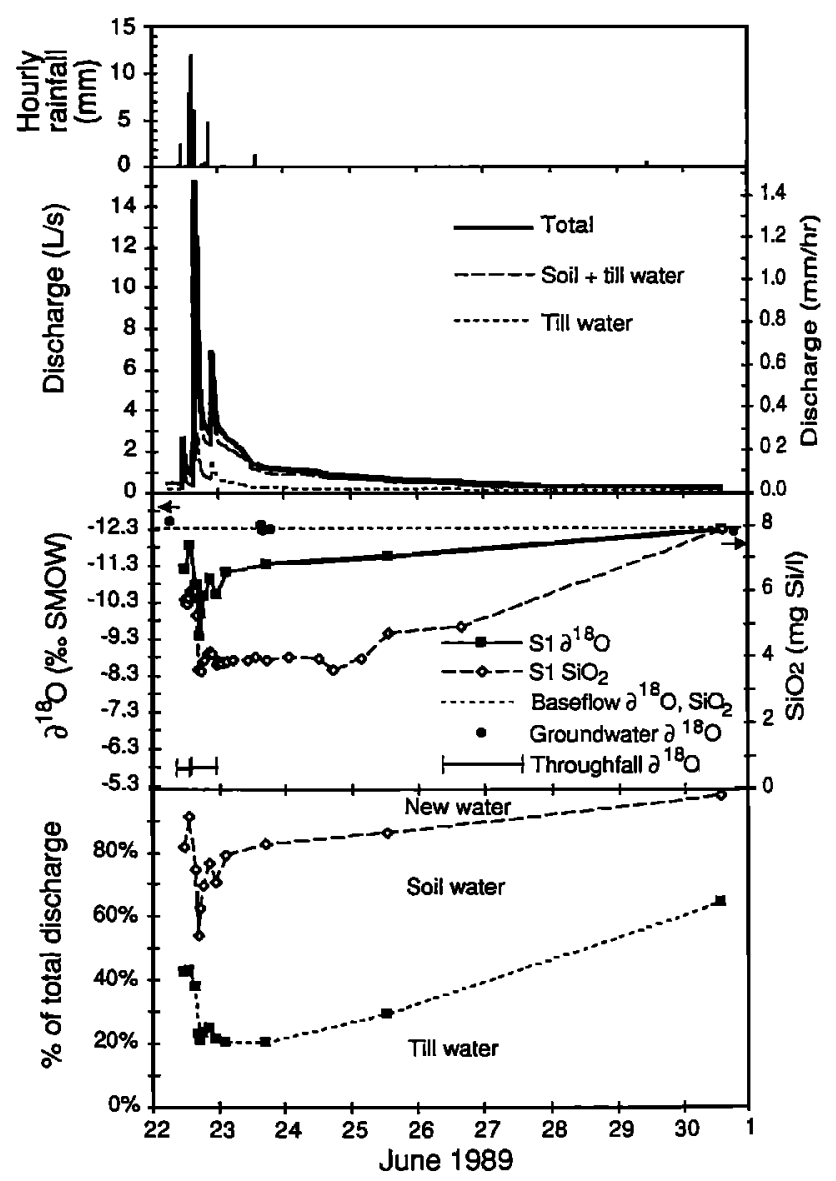

Figure 3. Three-component hydrograph separations for the June 22, 1989, event. Data and results are presented in Tables 1 and 2 . Dissolved silica and $\partial^{18} \mathrm{O}$ scales are selected so that new water and base flow water concentrations coincide. Arrows indicate samples collected prior to or following the displayed time period. 
dominates the storm hydrograph at $\mathrm{S} 1$ contributing $65 \%$ of peak discharge and $77 \%$ of the total hydrograph.

The flow paths of new water to the stream during these two events may be inferred from the total volumes of rainfall and new water runoff. Since the effective runoff (ratio of runoff/rainfall) for the June 22 storm is $47 \%$ and the ratio of new water to total runoff is $17 \%$, the area of saturated overland flow required to contribute new water directly to the stream is only $8 \%$ of the total basin area. Considering that the proportion of saturated area within the catchment varied between approximately $8-20 \%$ during the event, direct precipitation onto saturated areas is a plausible flow path for most of the new water entering the stream. Similarly, the intensities of rainfall and new water runoff can be compared. The peak intensity of new water stream discharge during this storm was $0.46 \mathrm{~mm} / \mathrm{h}$. If this value is compared with the maximum hourly rainfall intensity of $12 \mathrm{~mm} / \mathrm{h}$, then only $4 \%$ of the total catchment area is required to contribute the flux of new water at peak stream discharge.

The effective runoff and the proportion of new water discharge for the October 31 storm are 16 and $24 \%$, respectively, and direct precipitation contributed from only $4 \%$ of the catchment area is required to account for the total volume of new water. Considering that the peak intensity of new water stream discharge is only $0.08 \mathrm{~mm} / \mathrm{h}$ compared to the maximum rainfall intensity of $5.5 \mathrm{~mm} / \mathrm{h}$, then direct precipitation onto less than $2 \%$ of the catchment area is required to produce the flux of new water to the stream at peak discharge. From groundwater level measurements, the extent of surface saturation on October 31 is estimated to vary between approximately $3-7 \%$ during the event. Although these results suggest that direct precipitation onto saturated areas could be the major flow path of event water to the stream, the timing of the new water flow indicates that a small fraction of the new water is reaching the stream more slowly and is probably infiltrating the mineral soil. Visual observations indicate that saturation overland flow usually occurs beneath the litter within the surface organic horizons.

\section{Three-Component Hydrograph Separations Based on ${ }^{18} \mathrm{O}$ and $\mathrm{SiO}_{2}$}

Dissolved silica can be a useful tracer in many catchments since only trace amounts are usually found in precipitation [Likens et al., 1977; Wels et al., 1991a], whereas water that has sufficient contact time with the overburden frequently has dissolved enough $\mathrm{SiO}_{2}$ to be chemically distinct compared to precipitation. Making the assumption that new water does not dissolve any $\mathrm{SiO}_{2}$, Hooper and Shoemaker [1986] found that $\mathrm{SiO}_{2}$ was a suitable tracer to separate hydrographs into new and old components. In many catchments, infiltrating new water can dissolve $\mathrm{SiO}_{2}$ rapidly enough to make it indistinguishable from old water [McKeague and Cline, 1963; Kennedy, 1971] so that isotopic and $\mathrm{SiO}_{2}$ data can be combined to distinguish between new and old water flowing through the subsurface [Wels et al., 1991a; Maulé and Stein, 1990]. In catchments where till water has much higher $\mathrm{SiO}_{2}$ concentrations than either soil water or infiltrating event water, $\mathrm{SiO}_{2}$ can be used to distinguish between water flowing in the soil and water flow through the underlying tills [Hendershot et al., 1992].

The spatial pattern of $\mathrm{SiO}_{2}$ concentrations in Harp 4-21 reflects groundwater flow paths. Throughfall samples have trace amounts of $\mathrm{SiO}_{2}$. The average $\mathrm{SiO}_{2}$ concentration of

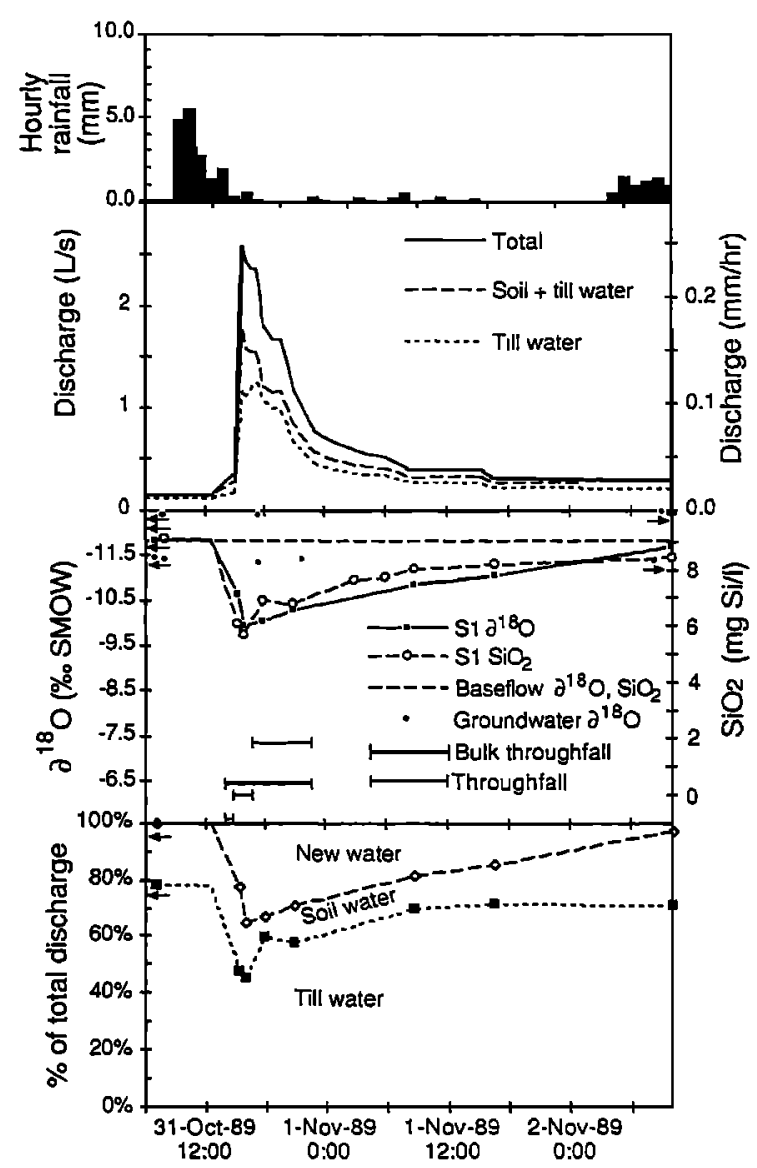

Figure 4. Three-component hydrograph separations for the October 31, 1989, event. Data and results are presented in Tables 1 and 2. Dissolved silica and $\partial^{18} \mathrm{O}$ scales are selected so that new and old water concentrations coincide. Arrows indicate samples collected prior to or following the displayed time period.

296 soil water samples collected by the MOE from lysimeters within Harp 4-21 during the study period is $2.54 \pm 1.53$ mg Si/L (B. LaZerte, unpublished data, 1992). However, groundwater $\mathrm{SiO}_{2}$ concentrations in the tills are significantly higher $(p<0.01)$ with a mean of $9.33 \pm 2.57 \mathrm{mg} \mathrm{Si} / \mathrm{L}(n=$ 137). Therefore $\mathrm{SiO}_{2}$ concentrations in the stream will vary according to the relative contributions of three water types: (1) new water that discharges to the stream during the event, (2) old soil water that has had little or no contact with the tills (soil water), and (3) longer residence time old water that has been in contact with the tills (till water). Note that this classification does not distinguish between vadose and phreatic water in the soils.

Hydrographs for the June 22 and October 31 events were separated into three components using ${ }^{18} \mathrm{O}$ and $\mathrm{SiO}_{2}$ as tracers in (4) and $\mathrm{SiO}_{2}$ as a tracer in (5) and (6). The input data are presented in Table 1 , and the hydrograph separations for June 22 event are shown graphically in Figure 5. Although soil water samples were not available for the storm events, soil water sampled for ${ }^{18} \mathrm{O}$ immediately before and after spring melt were not substantially different from groundwater ${ }^{18} \mathrm{O}$ in the tills. The soil water $\partial^{18} \mathrm{O}$ for the June 22 event was estimated to be $-12.54 \%$ o using the postmelt samples and the anticipated enrichment by the rainfall prior 
Table 1. Data Used to Calculate Three-Component Hydrograph Separations

\begin{tabular}{cccccccc}
\hline & \multicolumn{3}{c}{ June 22, 1989 } & & \multicolumn{3}{c}{ October 31, 1989 } \\
\cline { 2 - 4 } \cline { 7 - 8 } Component & $\begin{array}{c}\text { Best } \\
\text { Estimate }\end{array}$ & Lowest & Highest & & $\begin{array}{c}\text { Best } \\
\text { Estimate }\end{array}$ & Lowest & Highest \\
\hline$C_{n}^{S i}$ & 0.66 & 0.00 & 1.97 & & 0.66 & 0.00 & 1.97 \\
$C_{o s}^{S i}$ & 2.54 & 1.97 & 3.06 & & 2.54 & 1.97 & 3.06 \\
$C_{o t}^{S i}$ & 10.9 & 9.33 & 12.6 & & 10.9 & 9.33 & 12.6 \\
$C_{n}^{i}$ & -5.78 & -6.18 & -5.38 & & -6.43 & -6.83 & -6.03 \\
$C_{o s}^{i}$ & -12.54 & -13.91 & -11.90 & & -11.83 & -12.37 & -11.34 \\
$C_{o t}^{i}$ & -12.32 & -12.51 & -12.18 & & -11.83 & -12.37 & -11.34 \\
$C_{s}^{S i}$ & varies, shown in Figure 3 & & varies, shown in Figure 4 \\
$C_{s}^{i}$ & varies, shown in Figure 3 & & varies, shown in Figure 4 \\
\hline
\end{tabular}

Results are presented in Table 2 . Lowest and highest values are discussed in the text and are used to calculate the maximum range of till water in Table 2. The notation used for the various components are described in $(3)-(6)$. $\mathrm{SiO}_{2}$ concentrations are expressed in milligrams $\mathrm{Si}$ per liter and ${ }^{18} \mathrm{O}$ values are expressed in per mil.

to the event. Furthermore, samples collected from piezometers screened within the soils that only became saturated during the October 31 event were also similar to groundwater ${ }^{18} \mathrm{O}$ in the tills so that the base flow ${ }^{18} \mathrm{O}$ is assumed for both soil and till water for this event. Therefore the proportions of new and old water for the October 31 event are identical to the two-component model. Small differences between soil and till water ${ }^{18} \mathrm{O}$ have little effect on the proportion of till water for either event, since it is more greatly influenced by their $\mathrm{SiO}_{2}$ concentrations (discussed below).

The till water $\mathrm{SiO}_{2}$ concentration is assumed to equal the highest stream $\mathrm{SiO}_{2}$ concentration that occurred during low base flow conditions $(10.9 \mathrm{mg} / \mathrm{L}$ at S1) when inputs of soil water and new water are assumed to be negligible. Base flow is assumed to provide the best estimate of average till water $\mathrm{SiO}_{2}$ concentrations, since the till water $\mathrm{SiO}_{2}$ concentrations vary spatially and the average $\mathrm{SiO}_{2}$ concentration obtained from piezometers is biased by piezometers that are located upgradient from discharge areas or are screened at shallow depths. The average $\mathrm{SiO}_{2}$ concentration of $2.54 \mathrm{mg} / \mathrm{L}$ from soil lysimeters at all depths is used as the soil water

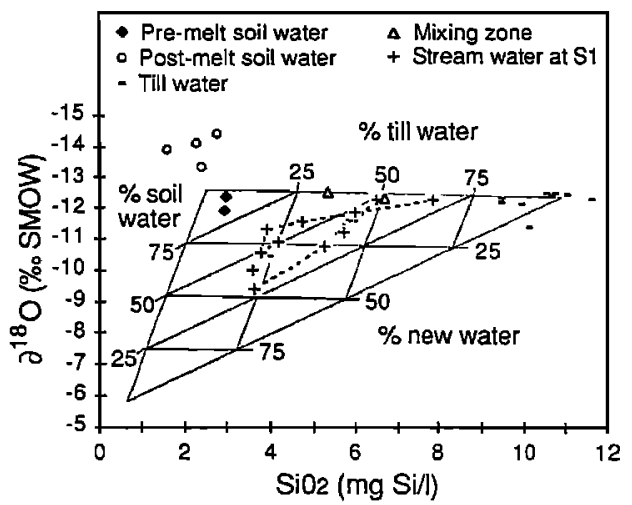

Figure 5. Graphical presentation of the three-component hydrograph separations for the June 22, 1989, event. Till water samples from the entire study period are shown. Mixing zone samples were collected from piezometer P11 before and following the event. concentration. Although precipitation in contact with the mineral soil may dissolve silica rapidly, the two-component isotopic hydrograph separation indicated that much of the new water component could reach the stream by saturation overland flow and therefore may have limited contact with the mineral soil. Laboratory leaching studies of similar podzolic soils suggest that infiltrating new water would not exceed a $\mathrm{SiO}_{2}$ concentration of $\approx 2.1 \mathrm{mg} / \mathrm{L}$ even after 7 days of contact with the soils [Wels, 1989]. There are few data for the new water Si concentration, since most overland flow samples are a mixture of new water and discharging old water. One sample, water discharging from the mineral soil nearly 24 hours following the last peak in streamflow during the June 22 event, had a $\mathrm{SiO}_{2}$ concentration of $0.66 \mathrm{mg} / \mathrm{L}$. This sample is a mixture of both new water and soil water but is used for both storms as a reasonable estimate of new water $\mathrm{SiO}_{2}$. Since the proportion of new water is relatively small, the results of the three-component hydrograph separations are relatively insensitive to the $\mathrm{SiO}_{2}$ value of the new water component in the range of $0-2 \mathrm{mg} / \mathrm{L}$.

Stream $\mathrm{SiO}_{2}$ concentrations, isotope ratios, and the resulting three-component hydrograph separations for the June 22 and the October 31 events are shown in Figures 3 and 4. respectively, and are summarized in Table 2 . In the June 22 event, till water contributes $29 \%$ of the total stream discharge and exceeds $20 \%$ of discharge throughout the event. In the October 31 event till water is the dominant component of storm runoff contributing $62 \%$ of total stream discharge at S1. Although the data are not presented here, the results also show that till water is the dominant component of flow at all stream sites during the October 31 event (Table 2). These results support the first hypothesis that groundwater flow through glacial tills can indeed contribute significantly to stream discharge during storms.

During the June 22 event, stream $\mathrm{SiO}_{2}$ concentrations decrease at peak discharge but do not return to base flow concentrations as rapidly as $\partial^{18} \mathrm{O}$ values (Figure 3 ). Three possible explanations for this difference between $\mathrm{SiO}_{2}$ and ${ }^{18} \mathrm{O}$ are (1) that the soil water contribution increases relative to that of till water, (2) that the relative proportions of soil and till water remain constant but the average $\mathrm{SiO}_{2}$ concentration of old soil water decreases during the event, and (3) 
Table 2. Summary of Results of Three-Component Hydrograph Separations Calculated Using (4)-(6) and Values in Table 1

\begin{tabular}{lcccc}
\hline & \multicolumn{4}{c}{ Total Event, \% of Total Runoff } \\
\cline { 2 - 5 } & New Water & Soil Water & Till Water & $\begin{array}{c}\text { Maximum Range } \\
\text { of Till Water }\end{array}$ \\
\hline June 22, 1989 & & & & \\
S1 & 20 & 51 & 29 & $17-43$ \\
October 31, 1989 & 23 & 15 & 62 & $46-72$ \\
S1 & 22 & 12 & 66 & \\
S2 & 25 & 9 & 66 & \\
S3 & 23 & 10 & 67 & \\
S4 & 29 & 4 & 67 & \\
S5 & & & & \\
\hline
\end{tabular}

that the average $\mathrm{SiO}_{2}$ concentration of till water decreases during the event as a result of precipitation of silicates or adsorption of $\mathrm{SiO}_{2}$. Figure 6 a shows the relative proportions of soil and till water in the old water component calculated from the three-component model assuming constant soil and till water $\mathrm{SiO}_{2}$ concentrations. Prior to the storm, till water makes up $50 \%$ of the old water discharge. This proportion decreases to $43 \%$ at peak discharge, reaches a minimum of 25\% approximately 24 hours following the last peak, and increases to $65 \%$ of old water discharge at baseflow following the storm (Figure 6a). Such changes in the relative

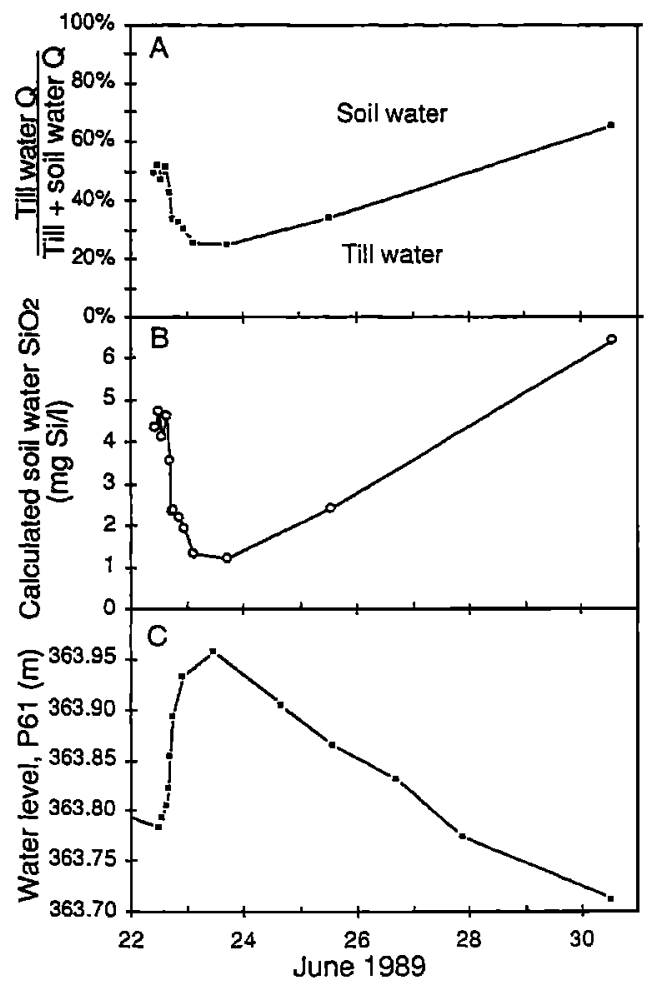

Figure 6. (a) The relative proportions of soil and till water during the June 22 event assuming constant soil and till water $\mathrm{SiO}_{2}$ concentrations. (b) The change in soil water $\mathrm{SiO}_{2}$ concentrations required to maintain constant relative proportions of soil and till water. (c) Coincident changes in water levels in piezometer P61. contribution of soil water and till water demonstrate a possible error that could arise in two-component hydrograph separations using $\mathrm{SiO}_{2}$ as a tracer. $\mathrm{SiO}_{2}$ traces the flow paths rather than the age of the water. If $\mathrm{SiO}_{2}$ were used to separate new and old water using baseflow $\mathrm{SiO}_{2}$ as the average old water concentrations ((1) and (2)), then the hydrograph separations would progressively underestimate the proportion of old water since, the average old water $\mathrm{SiO}_{2}$ concentration decreases during the storm as the proportion of soil water increases relative to that of till water. Conversely, if new water dissolves $\mathrm{SiO}_{2}$ then old water may be overestimated so that these errors may cancel one another.

Figure $6 \mathrm{~b}$ demonstrates the change in the average $\mathrm{SiO}_{2}$ concentration of old soil water that would be required if the relative contributions of soil water and till water were to remain constant. This change is unrealistic, since it would require average old soil water $\mathrm{SiO}_{2}$ concentrations of 6.4 $\mathrm{mg} / \mathrm{L}$ at base flow and $1.2 \mathrm{mg} / \mathrm{L}$ during the event. Using more realistic estimates of the possible changes in soil water $\mathrm{SiO}_{2}$ during an event shows that the relative change in soil and till water contributions is the dominant cause for the differences between the $\mathrm{SiO}_{2}$ and ${ }^{18} \mathrm{O}$ data.

Precipitation of silicates is not likely, since water from piezometers near the base of the till are still close to saturation with respect to clay minerals most likely to precipitate (S. N. Dankevy, unpublished manuscript, 1989). Furthermore, precipitation or adsorption would likely result in variations in the ratio of $\mathrm{SiO}_{2}$ to major cations. Figure 7 shows that $\mathrm{SiO}_{2}$ and the sum of major cations are highly

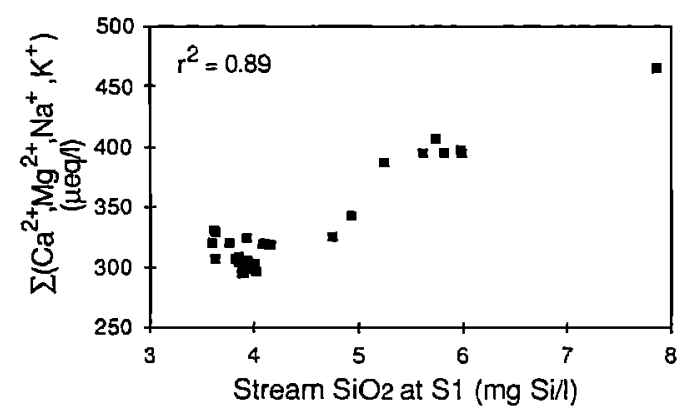

Figure 7. The correlation between $\mathrm{SiO}_{2}$ and the sum of major cations $\left(\mathrm{Ca}^{2+}, \mathrm{Mg}^{2+}, \mathrm{Na}^{+}, \mathrm{K}^{+}\right)$at $\mathrm{S} 1$ for the June 22 event. 


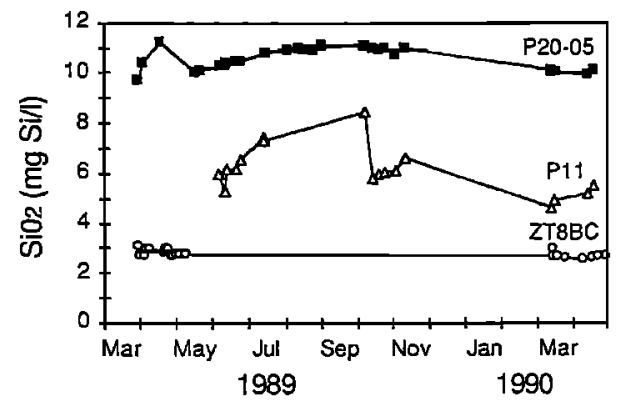

Figure 8. Temporal variations in $\mathrm{SiO}_{2}$ concentrations in till water (P20-05), soil water (ZT8BC), and in a zone of soil and till water mixing (P11).

correlated $\left(r^{2}=0.89\right)$ during the June 22 event suggesting that precipitation of silicates is minimal. If precipitation or adsorption was occurring then the till water component would be substantially higher than estimated by the threecomponent model.

Two processes may be responsible for the changes in the relative proportions of soil and till water. These changes correspond approximately to changes in piezometric heads during the event (Figure $6 \mathrm{c}$ ). It is possible that the rising water table within the soils is progressively saturating shallower, more conductive soil horizons and "releasing" vadose water from these horizons. This piezometer (P61) is located in a midslope area where tension saturation does not extend to the ground surface. Water levels in piezometers closer to the stream peak earlier but show the same gradual decline in water levels following the storm. Therefore the increase in the soil water component could also be attributed to a progressive spatial expansion of phreatic conditions within the soils. These explanations support the second hypothesis that attributes the change in the relative proportions of soil and till water to fluctuating water levels.

The changes in the stream $\mathrm{SiO}_{2}$ concentrations during the October 31 event follow the changes in $\partial^{18} \mathrm{O}$ values closely (Figure 4) suggesting that the relative proportions of soil water and till water do not vary as much as in the June 22 event. The proportion of old water that originates as till water decreases from $78 \%$ at base flow to $61 \%$ at peak discharge. Considerably lower groundwater levels would provide fewer opportunities to release vadose water from shallow soil horizons and the absence of phreatic conditions within the soil at P61 indicates that limited lateral expansion of phreatic conditions in the soil would provide much less soil water from midslope soils.

\section{Uncertainties in the Till Water Component}

In Harp 4-21 all the assumptions of the three-component model are not fulfilled. Consequently, the validity of the model is a function of the degree to which the assumptions are met and the results must be interpreted with consideration of these uncertainties. Figure 5 demonstrates that assumptions 1,2 , and 4 are reasonable. There is no apparent reason suggesting assumption 5 could be violated. The largest uncertainties in the three-component hydrograph separations in this study are likely to result from the assumption of constant $\mathrm{SiO}_{2}$ concentration for each of the three components. In fact, it is the spatially variable nature of $\mathrm{SiO}_{2}$ that allows hydrographs to be separated using $\mathrm{SiO}_{2}$.
Not only are there uncertainties in determining a spatially averaged $\mathrm{SiO}_{2}$ concentration of each component, but the concentrations of each component could also change during the event as a result of changing flow paths or changes in the spatial distribution of discharge throughout the catchment. As will be demonstrated below and in the subsequent section, these uncertainties have a minor influence on the relative proportions of the three components and they do not change the conclusion that the till water makes a significant contribution to stream discharge.

The $\mathrm{SiO}_{2}$ concentrations measured in till water shows only a slight seasonal fluctuation for any given piezometer (Figure 8). Although there are generally few data during dry conditions, soil lysimeters generally show relatively constant $\mathrm{SiO}_{2}$ concentrations and do not show large sudden changes (Figure 8). Changes in the average $\mathrm{SiO}_{2}$ concentrations for soil and till water components are more likely to result from changes in the spatial pattern of flow than from changes in the concentrations at any given location.

The sensitivity of the till water results are examined using the maximum expected range for the average $\mathrm{SiO}_{2}$ concentrations and $\partial^{18} \mathrm{O}$ values for each component (Table 2). The new water $\mathrm{SiO}_{2}$ concentration varies from $0 \mathrm{mg} / \mathrm{L}$ assuming no $\mathrm{SiO}_{2}$ dissolution to a maximum of $1.97 \mathrm{mg} / \mathrm{L}$ which is the average soil water $\mathrm{SiO}_{2}$ in all soil water samples collected from the A horizon. The maximum range for the average soil water $\mathrm{Si}$ concentration varies from 1.97 to $3.06 \mathrm{mg} / \mathrm{L}$, the average soil water concentrations of the $A$ and lowermost $B$ horizons, respectively. The maximum range of till water $\mathrm{SiO}_{2}$ concentrations varies from $9.33 \mathrm{mg} / \mathrm{L}$, the average of all piezometers screened in the tills, to $12.6 \mathrm{mg} / \mathrm{L}$, the largest $\mathrm{SiO}_{2}$ concentration measured from any piezometer. Note that this range is much larger than the calculated maximum range of 9.7 to $11.1 \mathrm{mg} / \mathrm{L}$ based on changes in the spatial pattern of stream discharge. Premelt and postmelt samples define the range for soil water $a^{18} \mathrm{O}$ for the June 22 event, whereas the maximum measured ranges for groundwater $\partial^{18} \mathrm{O}$ are used for soil and till water for the October 31 event. The analytical precision of $\pm 0.4 \% o(2 \sigma)$ is used to define the range for new water $\partial^{18} \mathrm{O}$, since the uncertainty in the average value is not known.

Despite the uncertainty in the $\mathrm{SiO}_{2}$ concentrations, the till water component is relatively insensitive to the range of concentrations possible within Harp 4-21 (Table 2). Till water is a substantial proportion of total runoff in both events, $17-43 \%$ on June 22 and $46-72 \%$ on October 31 . These ranges are artificially large, since the values in Table 1 can result in unrealistic negative values of new water or soil water. Because stream $\mathrm{SiO}_{2}$ concentrations were closest to those of till water, the results of the hydrograph separations are most sensitive to the till water $\mathrm{SiO}_{2}$ concentration. The average difference in the proportions of till water calculated using the highest and lowest till water $\mathrm{SiO}_{2}$ concentrations was $11 \%$. The results were less sensitive to the range of soil water $(6 \%)$ and new water $(5 \%) \mathrm{SiO}_{2}$ concentrations. The proportion of till water was relatively insensitive to the ranges of ${ }^{18} \mathrm{O}$ values of either new water $(<1 \%)$, soil water $(3 \%)$, or till water $(<1 \%)$.

\section{Two-Component Hydrograph Separations Based on $\mathrm{SiO}_{2}$}

Two-component hydrograph separations based on $\mathrm{SiO}_{2}$ concentrations are used to estimate the minimum proportion of till water during events for which isotopic data is either 
Table 3. Minimum Till Water Contributions at S1 During Runoff Events

\begin{tabular}{lccccr}
\hline \multicolumn{1}{c}{ Date } & $\begin{array}{c}\text { Peak } \\
\text { Discharge, } \\
\text { L/s }\end{array}$ & $\begin{array}{c}\text { Base Flow } \\
\mathrm{SiO}_{2}, \mathrm{mg} \\
\mathrm{Si} / \mathrm{L}\end{array}$ & $\begin{array}{c}\text { SiO } \\
\text { Discharge, } \\
\text { mg Si/L }\end{array}$ & $\begin{array}{c}\text { Base Flow, } \\
\%\end{array}$ & $\begin{array}{r}\text { Peak, } \\
\%\end{array}$ \\
\hline March 28, 1989 & 11.82 & 8.46 & 2.80 & 57 & $-3^{*}$ \\
April 4, 1989 & 2.04 & 6.22 & 4.54 & 33 & 16 \\
April 16, 1989 & 2.54 & 5.86 & 4.32 & 29 & 13 \\
April 25, 1989 & 4.77 & 3.98 & 2.96 & 10 & $-1^{*}$ \\
June 10, 1989 & 3.32 & 6.46 & 4.74 & 36 & 18 \\
June 20, 1989 & 1.19 & 7.54 & 6.14 & 47 & 32 \\
June 22, 1989 & 15.20 & 7.86 & 3.60 & 50 & 6 \\
Oct. 10, 1989 & 1.06 & 9.60 & 8.00 & 69 & 52 \\
Oct. 12, 1989 & 0.68 & 8.98 & 8.10 & 62 & 53 \\
Oct. 20, 1989 & 1.20 & 9.04 & 7.34 & 63 & 45 \\
Oct. 31, 1989 & 2.64 & 9.08 & 5.68 & 63 & 27 \\
Nov. 2, 1989 & 0.66 & 8.42 & 7.80 & 56 & 50 \\
Nov. 6, 1989 & 1.65 & 8.46 & 6.46 & 57 & 36 \\
March 15, 1990 & 5.18 & 8.04 & 3.64 & 52 & 6 \\
April 16, 1990 & 4.10 & 4.70 & 3.32 & 17 & 3 \\
\hline
\end{tabular}

Proportions were calculated from Si data using two-component hydrograph separations ((1) with $C_{n}=3.06 \mathrm{mg} / \mathrm{L}$ and $C_{0}=12.6 \mathrm{mg} / \mathrm{L}$ ).

*Peak discharge $\mathrm{SiO}_{2}$ less than maximum soil and new water $\mathrm{SiO}_{2}$.

unavailable or unsuitable. By assuming that the average $\mathrm{SiO}_{2}$ concentration of all new water and soil water does not exceed the average soil lysimeter concentration near the base of the B horizon in Harp 4-21 (3.06 mg/L, $n=52)$ and that the till water component has an average concentration equal to the maximum $\mathrm{SiO}_{2}$ of any piezometer $(12.6 \mathrm{mg} / \mathrm{L})$, then a two-component hydrograph separation (1) using these extreme values of $\mathrm{SiO}_{2}$ will indicate the minimum proportion of till water that could be discharged to the stream. This procedure is analogous to using a three-component model with $C_{n}^{\mathrm{Si}}=C_{o s}^{\mathrm{Si}}$ so that the second term of (6) equals zero.

The minimum till water contributions at baseflow and near peak flow for 15 runoff events are listed in Table 3. Till water contributes a significant proportion of discharge during several storms. Note that the values for the June 22 and October 31 events in Table 3 are extremely conservative relative to the three-component hydrograph separations in Table 2 . The relative importance of till water to stream discharge fluctuates according to groundwater levels (Figure 9). When groundwater levels are high during and following spring melt

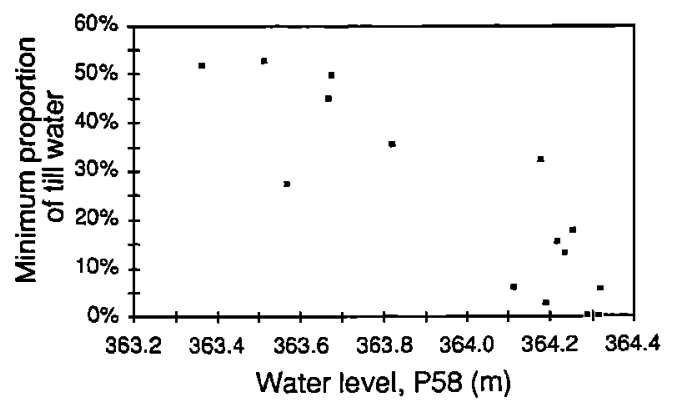

Figure 9. Influence of water levels in piezometer P58 on the minimum proportion of till water near peak discharge calculated using two-component hydrograph separations with $\mathrm{SiO}_{2}$ as a tracer. Hydrograph separation data are presented in Table 3. Negative values are plotted as $0 \%$ till water.
(Figure 2), the stream water $\mathrm{SiO}_{2}$ concentrations approach that of soil water indicating that the relative importance of till water is greatly reduced in comparison to the large fluxes of soil water. When groundwater levels are low in the autumn (Figure 2), even the minimum estimates of till water for different events remain in excess of $27 \%$ to $53 \%$ of peak stream discharge. Since groundwater levels are correlated between several piezometers, similar patterns are also observed in other piezometers close to the stream. This relation supports the second hypothesis that the seasonal changes in the till water component are related to water levels.

\section{Groundwater Flow From the Till to the Soil}

Since the glacial till sediments are not in direct contact with the stream, till water must flow through the soils prior to reaching the stream. Consequently, till water flow through the soil near the stream and mixes with soil water. The average $\mathrm{SiO}_{2}$ concentration of piezometers in this mixing zone is $6.73 \pm 2.16 \mathrm{mg} / \mathrm{L}$, intermediate between soil and till waters. Figure 8 shows the seasonal change in $\mathrm{SiO}_{2}$ concentration of a piezometer screened in the streambed. These variations probably result from a change in the relative proportions of soil and till water in this mixing zone. These changes correspond approximately to seasonal changes in water levels; more till water when water levels are lowest and more soil water when water levels are highest.

It is important to determine whether the till water flow during events (Figures 3 and 4) increases as a result of (1) an increase in groundwater flow from the tills to the soils and then to the stream or (2) from the flushing of till water that has already discharged to the soils prior to the event. In the first case, the till water flow depends on the hydraulic response in the tills. In the second case, the till water flow depends on the hydraulic response in the soils, the previous flow conditions in the soils and the ability of the tills to recharge the soils.

Figure 10a shows the piezometric response at three depths 


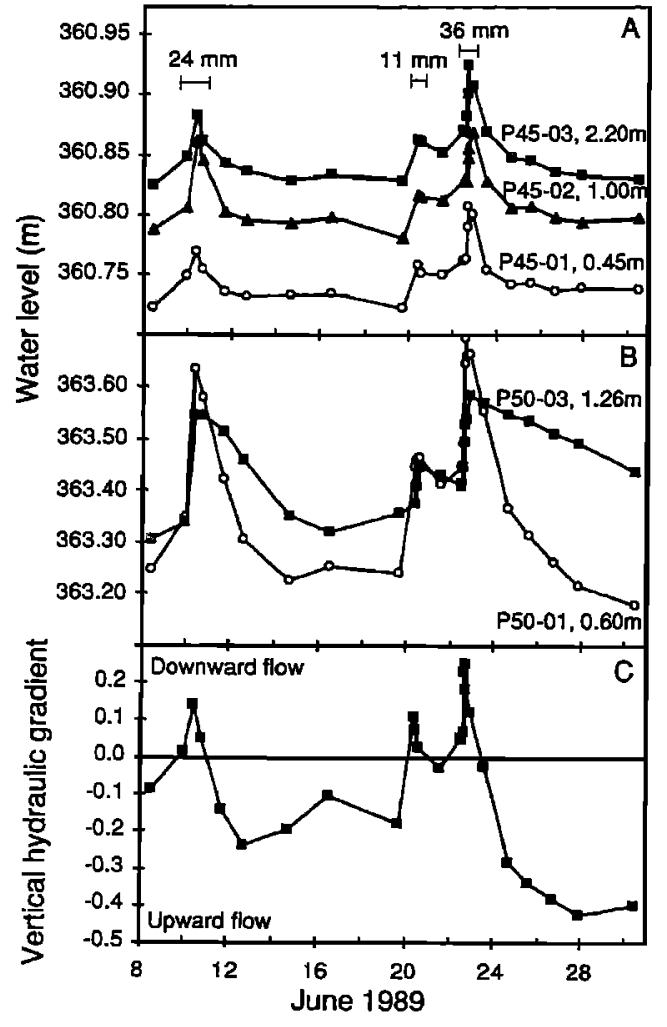

Figure 10. Water level changes during three June 1989 events in vertical piezometer nests (a) P45 and (b) P50 screened both in the soils (open symbols) and in the tills (solid symbols). (c) Changes in vertical gradients in P50 during the same events (positive upward). The depths of rainfall are indicated in Figure 10a.

beneath the streambed for three events in June 1989. The two deepest piezometers are screened in the till. The vertical gradient is upward indicating till water discharge toward the stream. The water levels fluctuate equally in all three piezometers showing that the vertical gradients between the till and the streambed remain nearly constant during the three events. Therefore there is no increase in till water flow into the streambed during the events.

Figures $10 \mathrm{~b}$ and $10 \mathrm{c}$ shows the piezometric response and the vertical hydraulic gradient between the till and the soil 25 m upslope from the stream for the same three events. The piezometric head in the soil increases rapidly but declines steadily following the peak. The piezometric head in the till increases less than in the soil but declines much more gradually following the peak. Consequently, there is a change in the direction of flow between the till and soil. At base flow, there is upward flow from the tills to the soils. On the rising limb and at peak there is downward flow from the soil to the till. Shortly after the peak, the upward flow resumes and even increases gradually following the June 22 event. The change to downward flow is coincident with the peak in till water discharge in the stream so that increased flow from the tills to the soils cannot explain the increase in till water flow to the stream. However, the change to upward flow between events suggests a process where till water can discharge to the soils and replace till water that was flushed out during the event. This flushing and gradual replenish- ment of till water in the soils is consistent with the rapid change and subsequent gradual recovery in the relative proportions of till and soil water shown in Figure 6.

\section{Summary and Conclusions}

Three-component hydrograph separations have provided insight into runoff generation. Although all the assumptions were not perfectly satisfied, the hydrograph separations were sufficiently accurate to address the goals of this paper. A two-component model based on ${ }^{18} \mathrm{O}$ would not have provided such insight. The additional information provided by the hydrometric data demonstrates the necessity of widening the scope of data collection beyond that of only stream water samples.

Whereas it would be extremely difficult to accurately quantify the flow of groundwater through the these tills using hydrometric measurements, the use of three-component hydrograph separations with two tracers has shown that despite the presence of compacted layers and relatively low hydraulic conductivity sediments within the tills $\left(10^{-5}\right.$ to $<10^{-9} \mathrm{~m} / \mathrm{s}$ ), till water is an important component of stream discharge. Therefore groundwater flow through glacial tills may have a significant influence on stream hydrology and chemistry in catchments with coarse-grained tills. Similar catchments may be numerous in regions where glacial tills are derived from granitic bedrock. Two-component hydrograph separations using $\mathrm{SiO}_{2}$ indicate the till water component varies seasonally and is related to water levels. The variation between the soil and till water components may be related both to the soil horizon in which water flows and to the spatial extent of phreatic conditions in the soils. Variations in the relative proportions of soil and till water during the June 22 event suggest a conceptual model where till water discharges to the soils near the stream between events and the soil and till water mixture is rapidly flushed from the soils to the stream during events. Measurements of vertical gradients between the soils and the tills in two locations support this conceptual model.

Many existing models of water flow or water chemistry for forested catchments rely on a conceptual model where flow is either lateral within a soil horizon or downward from the surface to the $\mathrm{A}, \mathrm{B}$, or $\mathrm{C}$ horizons. These models generally do not allow for deeper groundwater to flow to the stream through shallower soil horizons. The results of this paper suggest that such a model may not apply in Harp 4-21, since a substantial proportion of water discharges from the deeper tills into the shallow soil horizons and mixes with soil water prior to discharging to the stream. Further work in other catchments is needed to characterize the physical and hydraulic properties necessary to result in substantial groundwater flow into soils from the underlying bedrock or till.

Acknowledgments. We gratefully acknowledge the field assistance of Jayne and Alex MacLean during the June 22 event. Many other people also helped instrument the study site and collect field data. Their help is greatly appreciated. We also acknowledge the assistance of Peter Dillon, Bruce LaZerte, Lem Scott, and the Dorset Research Center (Ontario Ministry of the Environment) which provided financial and logistical support and unpublished data. One of us (M. J. Hinton) is supported by an NSERC postgraduate research grant. Many helpful comments from the three anonymous reviewers are acknowledged. 


\section{References}

Abdul, A. S., and R. W. Gillham, Laboratory studies of the effects of the capillary fringe on streamflow generation, Water Resour. Res., 20, 691-698, 1984.

Abdul, A. S., and R. W. Gillham, Field studies of the effects of the capillary fringe on streamflow generation, J. Hydrol., 112, 1-18, 1989.

Bishop, K. H., Episodic increases in stream acidity, catchment flow pathways and hydrograph separation, Ph.D. thesis, Univ. of Cambridge, Cambridge, England, 1991.

Blowes, D. W., and R. W. Gillham, The generation and quality of streamflow on uranium tailings near Elliot Lake, Ontario, $J$. Hydrol., 97, 1-23, 1988.

Bottomley, D. J., D. Craig, and L. M. Johnston, Neutralization of acid runoff by groundwater discharge to streams in Canadian Precambrian Shield watersheds, J. Hydrol., 75, 1-26, 1984.

Bottomley, D. J., D. Craig, and L. M. Johnston, Oxygen-18 studies of snowmelt runoff in a small Precambrian Shield watershed: Implications for streamwater acidification in acid-sensitive terrain, J. Hydrol., 88, 213-234, 1986.

Christophersen, N., H. M. Seip, and R. F. Wright, A model for streamwater chemistry at Birkenes, Norway, Water Resour. Res., 18, 977-996, 1982.

DeWalle, D. R., B. R. Swistock, and W. E. Sharpe, Threecomponent tracer model for stormflow on a small Appalachian forested catchment, J. Hydrol., 104, 301-310, 1988.

Dunne, T., T. R. Moore, and C. H. Taylor, Recognition and prediction of runoff-producing zones in humid regions, Hydrol. Sci. Bull., 20, 305-327, 1975.

Espeby, B., Water flow in a forested till slope, Ph.D. thesis, Dept. of Land and Water Resour., R. Inst. of Technol., Stockholm, Sweden, 1989.

Freeze, R. A., and J. A. Cherry, Groundwater, 604 pp., PrenticeHall, Englewood Cliffs, N. J., 1979.

Fritz, P., J. A. Cherry, K. U. Weyer, and M. Sklash, Storm runoff analyses using environmental isotopes and major ions, in Interpretation of Environmental Isotopes and Hydrogeochemical Data in Groundwater Hydrology, pp. 111-130, IAEA, Vienna, 1976.

Gherini, S. A., L. Mok, R. J. M. Hudson, G. F. Davis, C. W. Chen, and R. A. Goldstein, The ILWAS model: Formulation and application, Water Air Soil Pollut., 26, 425-459, 1985.

Hendershot, W. H., S. Savoie, and F. Courchesne, Simulation of stream-water chemistry with soil solution and groundwater flow contributions, J. Hydrol., 136, 237-252, 1992.

Hinton, M. J., S. L. Schiff, and M. C. English, Physical properties governing groundwater flow in a glacial till catchment, $J$. Hydrol., 142, 229-249, 1993.

Hooper, R. P., and C. A. Shoemaker, A comparison of chemical and isotopic hydrograph separation, Water Resour. Res., 22, 1444 $1454,1986$.

Jeffies, D. S., and W. R. Snyder, Geology and geochemistry of the Muskoka-Haliburton study area, Data Rep. Dr 83/2, 101 pp., Ont. Ministry of the Environ., Dorset, 1983.

Karrow, P. F., The texture, mineralogy and petrology of North American tills, in Glacial Till: An Interdisciplinary Study, Spec. Publ. Ser., vol. 12, edited by R. F. Legget, pp. 83-98, The Royal Society of Canada, Ottawa, Ont., 1979.

Kennedy, V. C., Silica variation in stream water with time and discharge, Adv. Chem. Ser., 106, 94-130, 1971.

Likens, G. E., H. Bormann, R. S. Pierce, J. S. Eaton, and N. M. Johnson, Biogeochemistry of a Forested Ecosystem, 146 pp., Springer-Verlag, New York, 1977.
Lozano, F. C., W. J. Parton, J. K. H. Lau, and L. Vanderstar, Physical and chemical properties of the soils at the southern biogeochemical study site, report, Fac. of For., Univ. of Toronto, Ont., 1987.

Maule, C. P., and J. Stein, Hydrologic flow path definition and partitioning of spring meltwater, Water Resour. Res., 26, 2959. $2970,1990$.

McDonnell, J. J., M. Bonell, M. K. Stewart, and A. J. Pearce, Deuterium variations in storm rainfall: Implications for stream hydrograph separation, Water Resour. Res., 26, 455-458, 1990.

McDonnell, J. J., M. K. Stewart, and I. F. Owens, Effects of catchment-scale subsurface mixing on stream isotopic response, Water Resour. Res., 27, 3065-3073, 1991.

McKeague, J. A., and M. G. Cline, Silica in soil solutions, 1, The form and concentration of dissolved silica in aqueous extracts of some soils, Can. J. Soil Sci., 43, 70-82, 1963.

Moore, R. D., Tracing runoff sources with deuterium and oxygen-18 during spring melt in a headwater catchment, Southern Laurentians, Quebec, J. Hydrol., 112, 135-148, 1989.

Ontario Ministry of the Environment (MOE), Handbook of analytical methods for environmental samples, Lab. Serv. Branch, Rexdale, 1983.

Rodhe, A., Spring flood, Meltwater or groundwater?, Nord. Hydrol., 12, 21-30, 1981.

Rodhe, A., Groundwater contribution to stream flow in Swedish forested till soil as estimated by oxygen-18, in Isotope Hydrology 1983, Rep. IAEA-SM-270/65, pp. 55-56, Int. At. Energy Agency, Vienna, 1984.

Rodhe, A., The origin of streamwater traced by oxygen-18, Ph.D. thesis, 260 pp., Dept. Phys. Geogr., Div. Hydrol., Uppsala Univ., Uppsala, Sweden, 1987.

Scott, J. S., Geology of Canadian tills, in Glacial Till: An Interdisciplinary Study, Spec. Publ. Ser., vol. 12, edited by R. F. Legget, pp. 50-66, The Royal Society of Canada, Ottawa, Ont., 1979.

Sklash, M., Final report on an environmental isotope survey to determine the role of groundwater in snowmelt runoff in the APIOS Harp 5 watershed, Rep. IRI 18-36, 94 pp., Ont. Ministry of the Environ., Toronto, 1986.

Sklash, M. G., and R. N. Farvolden, The role of groundwater in storm runoff, J. Hydrol., 43, 45-65, 1979.

Sklash, M. G., M. K. Stewart, and A. J. Pearce, Storm runoff generation in humid headwater catchments, $2, \mathrm{~A}$ case study of hillslope and low-order stream response, Water Resour. Res., 22, 1273-1282, 1986.

Wels, C., Streamflow generation in acidified headwater basins during spring runoff: an isotopic and geochemical approach, M.S. thesis, 213 pp., Trent Univ., Peterborough, Ont., 1989.

Wels, C., J. Cornett, and B. LaZerte, Hydrograph separation: A comparison of geochemical and isotopic tracers, J. Hydrol., I22, 253-274, 1991a.

Wels, C., C. Taylor, J. Cornett, and B. LaZerte, Streamflow generation in a headwater basin on the Precambrian Shield, Hydrol. Processes, 5, 185-199, $1991 \mathrm{~b}$.

M. C. English, Department of Geography, Wilfrid Laurier University, Waterloo, Ontario, Canada N2L 3C5.

M. J. Hinton and S. L. Schiff, Waterloo Centre for Groundwater Research, University of Waterloo, Waterloo, Ontario, Canada N2L $3 \mathrm{G} 1$.

(Received February 9, 1993; revised October 25, 1993; accepted November 15, 1993.) 